\title{
Études/Inuit/Studies
}

\section{Les Inuit urbains} Urban Inuit

\section{Nobuhiro Kishigami et Molly Lee}

Volume 32, numéro 1, 2008

Inuit urbains

Urban Inuit

URI : https://id.erudit.org/iderudit/029816ar

DOI : https://doi.org/10.7202/029816ar

Aller au sommaire du numéro

\section{Éditeur(s)}

Association Inuksiutiit Katimajiit Inc.

Centre interuniversitaire d'études et de recherches autochtones (CIÉRA)

\section{ISSN}

0701-1008 (imprimé)

1708-5268 (numérique)

Découvrir la revue

\section{Citer ce document}

Kishigami, N. \& Lee, M. (2008). Les Inuit urbains. Études/Inuit/Studies, 32(1),

5-11. https://doi.org/10.7202/029816ar d'utilisation que vous pouvez consulter en ligne.

https://apropos.erudit.org/fr/usagers/politique-dutilisation/ 


\title{
Les Inuit urbains
}

\author{
Rédacteurs invités: \\ Nobuhiro Kishigami* et Molly Lee ${ }^{* *}$
}

Les régions arctiques de l'Amérique du Nord et du Groenland sont habitées par des êtres humains depuis 4000 ans. À partir du 19e siècle, ceux-ci ont eu des contacts de plus en plus fréquents avec les Européens, puis, vers les années 1960, tous les peuples inuit, autrefois nomades, ont adopté un mode de vie sédentaire. Au cours des années 1960 et 1970, les études anthropologiques sur les Inuit se sont concentrées surtout sur les activités de subsistance, la famille et la parenté, et les changements sociaux et culturels se produisant chez les Inuit qui vivaient loin des centres urbains du sud. Même aujourd'hui, plusieurs recherches se concentrent sur une vie des Inuit dans l'Arctique qui en général n'est plus qu'un souvenir.

Indépendamment de ces tendances de la recherche sur les Inuit, deux phénomènes importants ont commencé à se manifester depuis les années 1980. Le premier est l'urbanisation des villages de l'Arctique. Cela s'accompagne souvent de mouvements de population, des plus petits villages vers les plus grands, comme Iqaluit. Le second est la spectaculaire augmentation de la population inuit dans les centres urbains du sud. Par exemple, le recensement canadien de 2006 montre qu'environ 20\% de la population totale des Inuit vit à l'extérieur des régions arctiques du Canada. Parmi les cas typiques d'urbanisation de l'Arctique, mentionnons les Inuit qui vivent dans des centres de population tels que Kotzebue et Barrow en Alaska, Iqaluit et Kuujjuaq au Canada, et Nuuk et Sisimiut au Groenland. Parmi les authentiques Inuit urbains, il y a ceux vivant aux États-Unis à Anchorage et Seattle, au Canada à Ottawa, Edmonton et Montréal, et au Danemark à Copenhague.

Puisque ces deux phénomènes sont relativement récents, ce n'est que maintenant qu'ils commencent à recevoir l'attention qu'ils méritent. Hamilton a étudié les schémas de migrations chez les jeunes Inuit du Groenland et de l'Alaska (voir Hamilton et al. 1996; Hamilton et Seyfrit 1993). Plus récemment, Fogel-Chance (1993), Sprott (1994) et Lee (2002) ont effectué des recherches sur les activités des femmes inupiat et yupik d'Anchorage et, depuis 1996, Kishigami $(2006,2008)$ a mené des enquêtes sur la vie des Inuit de Montréal. Cependant, très peu d'études anthropologiques se sont penchées sur la vie des Inuit dans les villages en voie d'urbanisation de l'Arctique et les centres urbains du sud, et il va sans dire qu'il existe encore moins de contributions à notre compréhension théorique de ces phénomènes.

\footnotetext{
* National Museum of Ethnology and the Graduate University for Advanced Studies, 10-1 Senri Expo Park, Suita City, Osaka, Japan 565-8511. inuit@idc.minpaku.ac.jp

** University of Alaska Museum, P.O. Box 6960, Fairbanks, AK 99775-6960, USA. ffmcl@uaf.edu
} 
Ce numéro thématique est le résultat d'un atelier intitulé «Les périphéries au centre: les Inuit dans les espaces urbains», qui devait à l'origine se tenir à San Francisco, en 2004, dans le cadre du congrès annuel de l'American Anthropological Association. Bien que ce congrès ait été annulé, l'atelier se tint néanmoins dans le Hall Kroeber de l'Université de Californie, à Berkeley, en décembre 2004, grâce à l'aide du professeur Nelson Graburn.

Ce numéro spécial évoque les cas particuliers de Nuuk au Groenland, de Fairbanks en Alaska, et d'Ottawa et Montréal au Canada. Dybbroe présente une discussion théorique de ce que représente l'urbanisation de l'Arctique à partir de différents cas au Groenland. Ryggard et Pedersen se penchent sur la vie des jeunes inuit de Nuuk. Patrick et Tomiak abordent des questions d'enseignement relatives à la culture et à la langue inuit à Ottawa. Kishigami décrit les problèmes des Inuit sans-abri à Montréal. Enfin, Blackman se concentre sur les cas de certains Inupiat venus d'Anaktuvuk Pass et qui ont séjourné ou se sont installés à Fairbanks pour diverses raisons.

Bien que les articles de ce numéro thématique ne puissent aborder qu'un nombre limité de questions relatives aux Inuit urbains, il s'agit du premier collectif consacré spécifiquement à ce sujet et qui rassemble les perspectives de trois pays. Dans un proche avenir, les études portant sur les Inuit urbains deviendront de plus en plus nécessaires et constitueront un important domaine de recherche, tant dans les sphères universitaires que pratiques. Les rédacteurs invités, autant que les auteurs ayant apporté leur contribution à ce numéro thématique, pensent que celui-ci constituera un nouveau chapitre des études inuit, nées il y a plus de 100 ans avec les recherches de Franz Boas.

\section{Références}

FOGEL-CHANCE, Nancy

1993 Living in Both Worlds: 'Modernity' and 'Tradition' among North Slope Inupiaq Women in Anchorage, Arctic Anthropology, 30(1): 94-108.

HAMILTON, Lawrence C., Rasmus O. RASMUSSEN, Nicolas E. FLANDERS et Carole L. SEYFRIT

1996 Outmigration and Gender Balance in Greenland, Arctic Anthropology, 33(1): 89-97.

HAMILTON, Lawrence C. et Carole L. SEYFRIT

1993 Town-Village Contrasts in Alaska Youth Aspirations, Arctic, 46(3): 255263.

KISHIGAMI, Nobuhiro

2006 Inuit Social Networks in an Urban Setting, in P. Stern et L. Stevenson (dir.), Critical Inuit Studies: An Anthology of Contemporary Arctic Ethnography, Lincoln, University of Nebraska Press: 206-216. 
2008 Notes on Information and Food-resource Flow among the Urban Inuit in Montreal, Canada, Journal of the Society of Liberal Arts, 77: 199-210.

LEE, Molly

2002 The Cooler Ring: Urban Alaska Native Women and the Subsistence Debate, Arctic Anthropology, 30: 3-9.

SPROTT, Julie E.

1994 "Symbolic Ethnicity" and Alaska Natives of Mixed Ancestry Living in Anchorage, Human Organization, 53(4): 311-322. 



\section{Urban Inuit}

\section{Guest editors: Nobuhiro Kishigami* and Molly Lee**}

Human beings have inhabited the Arctic regions of North America and Greenland for the last 4,000 years. Beginning in the 19th century, they came increasingly into contact with Europeans and by the 1960s all Inuit peoples, who were formerly nomadic, had adopted a sedentary way of life. During the 1960s and 1970s, anthropological studies about the Inuit focused primarily on subsistence activities, family and kinship, and social and cultural changes of the Inuit living far way from urban centres in the south. Even today, several studies concentrate on an Inuit life in an Arctic that exists largely in memory.

Despite these trends in Inuit research, two important phenomena have begun to emerge beginning in the 1980s. The first is urbanisation of villages in the Arctic. This is often accompanied by population movements from smaller villages into larger ones such as Iqaluit. The second is the dramatic increase of Inuit in urban centres in the South. For example, the 2006 Canada census shows that about $20 \%$ of the Inuit total population live outside the Arctic regions of Canada. Typical cases of Arctic urbanisation are Inuit living in such northern populations centres as Kotzebue and Barrow in Alaska, Iqaluit and Kuujjuaq in Canada, and Nuuk and Sisimiut in Greenland. Examples of bona fide urban Inuit are those living in Anchorage and Seattle, USA, in Ottawa, Edmonton, and Montreal, Canada, and in Copenhagen, Denmark.

Because these two phenomena are relatively recent they are only now beginning to receive the attention they deserve. Hamilton studied migration patterns among Inuit youth in Greenland and Alaska (e.g., Hamilton et al. 1996; Hamilton and Seyfrit 1993). More recently, Fogel-Chance (1993), Sprott (1994) and Lee (2002) have done research on the activities of Inupiat and Yupik women in Anchorage, and since 1996 Kishigami (e.g., 2006, 2008) has conducted surveys on the life of Inuit in Montreal. Yet, there are few anthropological studies examining Inuit life in the urbanising Arctic villages and southern urban centres, to say nothing of contributions to our theoretical understanding of these phenomena.

This special issue of the volume is a result of a session entitled "Peripherals at the center: Inuit in Urban Spaces" that was originally organised for the annual meeting of the American Anthropological Association held in San Francisco in 2004. Although the

\footnotetext{
* National Museum of Ethnology and the Graduate University for Advanced Studies, 10-1 Senri Expo Park, Suita City, Osaka, Japan 565-8511. inuit@idc.minpaku.ac.jp

** University of Alaska Museum, P.O. Box 6960, Fairbanks, AK 99775-6960, USA. ffmcl@uaf.edu
} 
meeting was cancelled, the session itself was held nonetheless at Kroeber Hall at the University of California, Berkeley, in December 2004, with the kind assistance of Professor Nelson Graburn.

This special issue takes up cases from Nuuk, Greenland, Fairbanks, Alaska, and Ottawa and Montreal, Canada. Dybbroe discusses in a theoretical way what Arctic urbanisation is, with cases from Greenland. Rygaard and Pedersen examine the life of young Inuit in Nuuk. Patrick and Tomiak deal with education issues linked to Inuit culture and language in Ottawa. Kishigami describes the problems of the homeless Inuit in Montreal. Finally, Blackman concentrates on the cases of Inupiat from Anaktuvuk Pass who were visiting and/or staying in Fairbanks for various purposes.

Although the papers of this special issue deal with only a limited number of issues related to urban Inuit, it is the first collective volume specifically on this subject and covering perspectives from three countries. In the near future, urban Inuit studies will become increasingly necessary and will constitute an important area of research in both academic and practical spheres. Both the guest editors as well as the contributors believe that this special issue opens a new page of Inuit studies, which originated more than 100 years ago with the research of Franz Boas.

\section{References}

FOGEL-CHANCE, Nancy

1993 Living in Both Worlds: 'Modernity' and 'Tradition' among North Slope Inupiaq Women in Anchorage, Arctic Anthropology, 30(1): 94-108.

HAMILTON, Lawrence C., Rasmus O. RASMUSSEN, Nicolas E. FLANDERS and Carole L. SEYFRIT

1996 Outmigration and Gender Balance in Greenland, Arctic Anthropology, 33(1): 89-97.

HAMILTON, Lawrence C. and Carole L. SEYFRIT

1993 Town-Village Contrasts in Alaska Youth Aspirations, Arctic, 46(3): 255263.

KISHIGAMI, Nobuhiro

2006 Inuit Social Networks in an Urban Setting, in P. Stern and L. Stevenson (eds), Critical Inuit Studies: An Anthology of Contemporary Arctic Ethnography, Lincoln, University of Nebraska Press: 206-216.

2008 Notes on Information and Food-resource Flow among the Urban Inuit in Montreal, Canada, Journal of the Society of Liberal Arts, 77: 199-210.

LEE, Molly

2002 The Cooler Ring: Urban Alaska Native Women and the Subsistence Debate, Arctic Anthropology, 30: 3-9. 
SPROTT, Julie E.

1994 "Symbolic Ethnicity" and Alaska Natives of Mixed Ancestry Living in Anchorage, Human Organization, 53(4): 311-322. 